\title{
PENYUSUNAN KERANGKA KONSEPTUAL PENGUKURAN KUALITAS SISTEM INFORMASI AKADEMIK DI KAMPUS STIKI MALANG BERDASARKAN STANDARD ISO 9126
}

\author{
Addin Aditya*1, Febry Eka Purwiantono \\ ${ }^{1}$ Sistem Informasi, STIKI Malang, ${ }^{2}$ Manajemen Informatika STIKI Malang \\ Email: ${ }^{1}$ addin@stiki.ac.id, ${ }^{2}$ febry@stiki.ac.id \\ *Penulis Korespondensi
}

(Naskah masuk: 31 Desember 2018, diterima untuk diterbitkan: 07 Oktober 2020)

\begin{abstract}
Abstrak
Perkembangan sistem dan teknologi informasi yang pesat membawa berbagai macam dampak pada institusi perguruan tinggi. Hampir seluruh perguruan tinggi di Indonesia sudah mengadopsi teknologi informasi sebagai media untuk melakukan proses belajar mengajar. Salah satu teknologi yang sudah sering diadopsi adalah Sistem Informasi Akademik (SIA) yang berfungsi sebagai fasilitator IT dalam menyelenggarakan kegiatan yang bersifat akademik. Namun demikian, dengan penerapan Sistem Informasi Akademik ini pun masih meninggalkan berbagai macam pertanyaan terkait dengan pemanfaatan SIA tersebut. Penelitian ini bertujuan untuk mengukur kualitas sebuah perangkat lunak dari segi fungsional, keandalan, kebergunaan, efisiensi, pemeliharaan dan portabilitas. Hasil dari pengukuran tersebut diharapkan menjadi bahan evaluasi untuk peningkatan sistem yang berkelanjutan. Adapun metode penelitian yang digunakan adalah metode deskriptif dimana data dikumpulkan dengan cara menyebar kuesioner serta melakukan wawancara terhadap beberapa stakeholder sistem. Atribut-atribut yang digunakan dalam pembuatan kuesioner nantinya akan dijadikan dasar untuk perbaikan kualitas pada perangkat lunak. Diharapkan model yang diusulkan dapat dijadikan kerangka acuan untuk perbaikan kualitas bagi perangkat lunak di lingkup akademik perguruan tinggi khususnya bagian akademik dan unit penunjang lain pada umumnya. Hasil analisis menunjukkan bahwa sistem dinilai baik ditinjau dari semua karakteristik software berdasarkan ISO 9126.
\end{abstract}

Kata kunci: Sistem Informasi Akademik, ISO 9126, evaluasi perangkat lunak, pemodelan

\section{DEVELOPING A CONCEPTUAL FRAMEWORK TO EVALUATE THE ACADEMIC INFORMATION SYSTEM IN STIKI MALANG BASED ON ISO 9126}

\begin{abstract}
The rapid growth of information technology has brought a significant change to academic institution, especially to higher education. Almost all of Indonesia higher education has adopted the information technology as a learning media. Academic Information System is one of the technologies that adopted for academic purposes. However, there are still many gaps in developing and implementing the system. This research aims to evaluate the performance of Academic Information System and measure its quality based on the functionality, reliability, usability, efficiency, maintainability and portability where all this element is exist in ISO 9126 as our guide for measuring the quality. We use a questionnaire and interview the stakeholders to collect data. The attributes in the questionnaire will used as a guidance to build a baseline framework. We hope this will be a good proposed model that can be a main reference for academic and other related units. The result shows that all system characteristic has a good point based on ISO 9126.
\end{abstract}

Keywords: Academic Information System, ISO 9126, modelling, software evaluation

\section{PENDAHULUAN}

Penerapan teknologi informasi di Indonesia saat ini sudah menjadi kebutuhan utama bagi masyarakat dari berbagai lapisan dan latar belakang Pendidikan. Sudah tak terhitung berapa banyak jenis teknologi informasi yang sudah diterapkan untuk mempermudah proses bisnis dalam suatu organisasi. Dunia Pendidikan juga tidak absen dalam memanfaatkan teknologi informasi untuk sebagai fasilitator dan media pembelajaran. Dalam berbagai tingkat Pendidikan, perguruan tinggi paling sering memanfaatkan teknologi informasi dalam 
menyelenggarakan kegiatan belajar mengajar. Salah satu adopsi teknologi yang diterapkan oleh perguruan tinggi adalah sistem informasi akademik (SIA). Hampir seluruh perguruan tinggi menggunakan sistem e-learning untuk membantu pembelajaran tatap muka atau untuk mengimplementasikan pembelajaran jarak jauh dan sistem ini sering disebut dengan Course Management System (Padayachee, 2010). Pengguna SIA dapat diklasifikasikan berdasarkan peran dan fungsinya dalam manajemen akademik sesuai dalam struktur organisasi dalam institusi yang bersangkutan.

Kampus STIKI Malang adalah salah satu perguruan tinggi yang sudah memanfaatkan teknologi informasi dalam menyelenggarakan kegiatan akademik. Kampus STIKI telah menyediakan Sistem Informasi Akademik bernama SAKTI (Sistem Informasi Akademik STIKI). Namun, kualitas SAKTI masih perlu dievaluasi dan ditingkatkan sebagai bentuk penyesuaian pada dinamika sistem dan kebutuhan pengguna. Perlu disadari pula bahwa masih banyak pengguna yang belum memahami dan berpengalaman dalam implementasi SAKTI. Keberhasilan sebuah sistem informasi akademik bergantung pada seberapa jauh keselarasannya terhadap proses-proses bisnis yang ada (Scott, 1986).

Sebagai upaya peningkatan kualitas sebuah sistem, ISO 9126 layak untuk dijadikan kerangka standard (Simanjuntak, 2013). Standard ini dibuat untuk mengidentifikasi atribut-atribut apa saja yang terkait dengan perbaikan kualitas SIA. Standard ini mengklasifikasikan atribut keberhasilan suatu sistem menjadi 6 bagian. Diantaranya fungsionalitas, keandalan, kebergunaan, efisiensi, kemudahan pemeliharaan dan portabilitas. Implementasi atributatribut ini mengoptimalkan hubungan antara SIA dan proses akademik yang terjadi di Kampus STIKI Malang.

Penelitian ini bertujuan untuk mengusulkan sebuah model aplikasi evaluasi perangkat lunak Sistem Informasi Akademik di Kampus STIKI berlandaskan standard ISO 9126. Usulan model diharapkan dapat dijadikan acuan dalam mengevaluasi dan meningkatkan kualitas aplikasi SAKTI agar dapat berjalan lebih baik dan dapat menyesuaikan dengan dinamika Pendidikan di perguruan tinggi.

\subsection{Penelitian Terkait}

Pada penelitian milik Febrero et.al (2016) dengan judul "Software Reliability Modelling based on ISO/IEC Square" bertujuan mengidentifikasi dan menganalisis pekerjaan yang ada dengan memodelkan keandalan perangkat lunak berdasarkan standar internasional sebagai titik awal untuk pengujian reliabilitas berdasarkan ISO/IEC 25000 Software Product Quality Requirement and Evaluation (SQuaRE). Hasil dari penelitian ini adalah kompleksitas model dan kompleksitas penerapan system menjadi akar penyebabnya. Berbagai kebutuhan dari stakeholders juga merupakan hal yang penting untuk penerapan industry apabila model yang diusulkan akan diperbaiki (Febrero, Calero and Moraga, 2016).

Hal senada juga disampaikan dalam penelitian milik Ouhbi et.al (2015) bahwa persyaratan kualitas produk perangkat lunak mencerminkan kebutuhan para pemangku keputusan. Mereka memainkan peran sentral dalam keberhasilan system dan kualitas perangkat lunak. Pada penelitian ini model kualitas perangkat lunak oleh ISO/IEC 25010 digunakan untuk menyajikan daftar yang dapat digunakan untuk menghitung pengaruh persyaratan catatan rekam medik berbasis mobile pada kualitas produk perangkat lunak. Dari pengujian ini munculah beberapa usulan untuk perbaikan system, diantaranya adalah penggunaan layanan komputasi awan untuk mekanisme penyimpanan dan transfer data (Ouhbi et al., 2015).

\subsection{Sistem Informasi Akademik}

Sistem informasi Akademik berfungsi untuk memfasilitasi para civitas akademika untuk menyelenggarakan kegiatan Tri Dharma Perguruan Tinggi terutama dalam bidang administrasi. Administrasi disini mengandung pengertian serangkaian kegiatan yang bertujuan untuk kelancaran kegiatan akademik dengan mengadakan kegiatan pengelolaan dan pengorganisasian terhadap aktivitas dan sumber daya di dalamnya.

Data yang diterima oleh SIA akan diproses sedemikian rupa untuk dijadikan informasi untuk selanjutnya akan memunculkan pengetahuan (Simanjuntak, 2013). Proses utama ini dimanfaatkan untuk menyelesaikan tugas administratif dan bersifat transaksional semisal pendaftaran mahasiswa baru, penjadwalan mata kuliah, pencetakan FRS (Formulir Rencana Studi), pencetakan KHS (Kartu Hasil Studi) dan lain sebagainya. Sejalan dengan kegiatan di dunia manajemen, data dan informasi dapat pula digunakan sebagai pendukung tata kelola organisasi meliputi membuat rencana kerja, pengorganisasian, implementasi serta monitoring dan evaluasi.

\subsection{Standard ISO 9126}

Serangkaian kegiatan untuk mengeksekusi dan mengidentifikasi apakah sebuah perangkat lunak memiliki kesalahan ataukah sudah berjalan sebagaimana mestinya disebut dengan pengujian perangkat lunak. Kegiatan ini bertujuan untuk penjaminan kualitas perangkat lunak serta representasi sistem, spesifikasi, desain program dan pengkodean.

ISO 9126 adalah salah satu kerangka standar internasional yang berfungsi mengukur kualitas perangkat lunak yang dibuat oleh International Standard Organization (ISO) dan International 
Electrotechnical Commission (IEC). Model ISO 9126 memiliki enam factor dan beberapa sub faktor (Weber and A., 1999).

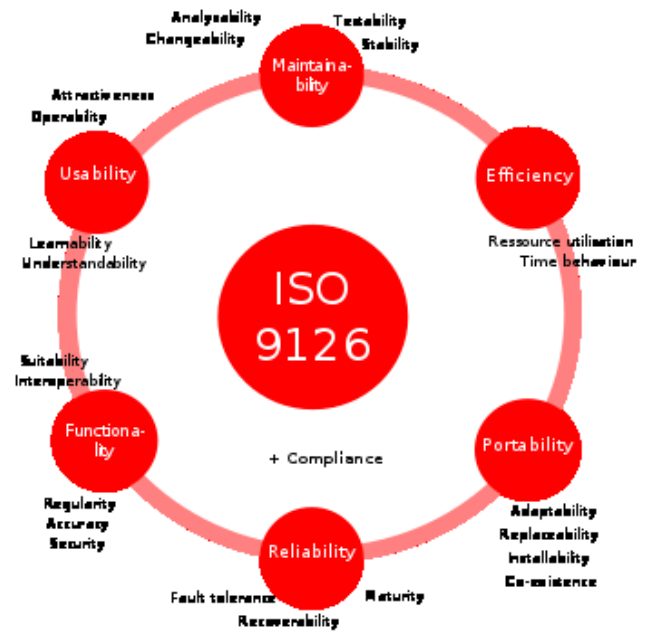

Gambar 1. Faktor dan Sub Faktor Pengukuran Kualitas Berdasarkan ISO 9126

Berdasarkan gambar 1, berikut adalah paparan mengenai karakteristik ISO 9126:

\section{Fungsionalitas}

Kemampuan perngkat lunak untuk memfasilitasi kebutuhan pengguna. SIA harus dapat diakses di berbagai platform tanpa mengurangi tujuan utamanya. Karakteristik ini memiliki sub atribut kecocokan, akurasi, interoperabilitas, kesesuaian dan keamanan

\section{Keandalan}

Kemampuan piranti lunak untuk mempertahankan performanya dalam kondisi apapun. Sub atribut yang dimiliki adalah kematangan, toleransi kesalahan, kemampuan untuk melakukan recovery

\section{Kebergunaan}

Aspek ini membahas tentang kepuasan pengguna dari sisi fungsi dan kebergunaan sistem. Karakteristik ini memiliki sub atribut: kemudahan untuk dipahami, kemudahan untuk dipelajari dan operabilitas

\section{Efisiensi}

Aspek ini membahas mengenai bagaimana sumber daya yang digunakan dapat mencapai nilai optimalnya. Sub atributnya: waktu, sumber daya,

\section{Pemeliharaan}

Kemudahan tentang bagaimana melakukan perbaikan yang mungkin dilakukan pada perangkat lunak. Sub atribut yang dimiliki: Sistem mampu melakukan error analysis, sistem dapat dimodifikasi dan tetap stabil serta sistem dapat divalidasi.

\section{Portabilitas}

Kemampuan perangkat lunak untuk beradaptasi dengan berbagai macam lingkungan namun tidak mengurangi fungsi utamanya. Sub atributnya adalah adaptasi dengan platform, kemampuan untuk diinstall, kesesuaian dan kemampuan untuk digantikan.

Serangkaian kegiatan yang bertujuan untuk menilai apakah system sudah terintegrasi dan mampu membantu proses bisnis yang ada di sebuah institusi dengan mengumpulkan dan mengevaluasi data dan proses disebut juga dengan pengujian sistem informasi. Kegiatan pengujian sistem informasi pada beberapa perguruan tinggi mengacu pada standar ISO 9261 karena standar tersebut memiliki keluasan cakupan pengelolaan dan detail prosesnya sehingga diharapkan dapat menjadi kerangka acuan yang jelas untuk bisa diterapkan dalam penggunaan sistem yang lain (Pamungkas, 2018).

Masing-masing karakteristik kualitas perangkat lunak model ISO 9126 dibagi menjadi beberapa subkarakteristik yang dapat dilihat pada tabel berikut (Lailela and Suwartika, 2018):

Tabel 1. Karakteristik Perangkat Lunak

\begin{tabular}{|c|c|}
\hline Sub-Karakteristik & Deskripsi \\
\hline \multicolumn{2}{|c|}{ FUNCTIONALITY } \\
\hline Suitability & $\begin{array}{l}\text { Kemampuan sistem untuk } \\
\text { menyediakan dan melaksanakan } \\
\text { serangkaian fungsi utama untuk } \\
\text { memenuhi tujuan organisasi }\end{array}$ \\
\hline Accuracy & $\begin{array}{l}\text { Kemampuan sistem untuk } \\
\text { memberikan output yang selaras } \\
\text { dengan tujuan organisasi }\end{array}$ \\
\hline security & $\begin{array}{l}\text { Kemampuan sistem untuk } \\
\text { menyediakan hak akses user dan } \\
\text { otorisasi data guna mencegah hal } \\
\text { yang tidak diinginkan }\end{array}$ \\
\hline interoperability & $\begin{array}{l}\text { Kemampuan sistem untuk dapat } \\
\text { bersinergi dengan modul atau } \\
\text { sistem yang lain }\end{array}$ \\
\hline compliance & $\begin{array}{l}\text { Kemampuan perangkat lunak } \\
\text { untuk mematuhi standard dan } \\
\text { kebutuhan }\end{array}$ \\
\hline \multicolumn{2}{|r|}{ USABILITY } \\
\hline Understandability & $\begin{array}{l}\text { Perangkat lunak mudah untuk } \\
\text { dipahami }\end{array}$ \\
\hline learnability & $\begin{array}{l}\text { Perangkat lunak dapat dipelajari } \\
\text { dengan mudah }\end{array}$ \\
\hline operability & $\begin{array}{l}\text { Perangkat lunak mudah untuk } \\
\text { dioperasikan }\end{array}$ \\
\hline attractiveness & $\begin{array}{l}\text { Kemampuan perangkat lunak } \\
\text { dalam menarik minat pengguna }\end{array}$ \\
\hline \multicolumn{2}{|r|}{ EFFICIENCY } \\
\hline Time behavior & $\begin{array}{l}\text { Kemampuan system untuk } \\
\text { merespon dan memproses sesuai } \\
\text { dengan waktu yang telah } \\
\text { disepakati }\end{array}$ \\
\hline Resource behavior & $\begin{array}{l}\text { Kemampuan system untuk } \\
\text { memanfaatkan sumber daya untuk } \\
\text { melaksanakan fungsi utama }\end{array}$ \\
\hline \multicolumn{2}{|c|}{ MAINTAINABILITY } \\
\hline
\end{tabular}




\begin{tabular}{ll}
\hline Sub-Karakteristik & \multicolumn{1}{c}{ Deskripsi } \\
\hline analyzability & $\begin{array}{l}\text { Kemampuan untuk dapat } \\
\text { menganalisa penyebab kegagalan } \\
\text { system }\end{array}$ \\
\hline changeability & $\begin{array}{l}\text { Kemampuan sistem untuk dapat } \\
\text { dimodifikasi }\end{array}$ \\
\hline stability & $\begin{array}{l}\text { Kestabilan system pasca } \\
\text { modifikasi }\end{array}$ \\
\hline testability & $\begin{array}{l}\text { System dapat dimodifikasi dan } \\
\text { divalidasi }\end{array}$ \\
\hline PORTABILITY \\
\hline Pdaptability & $\begin{array}{l}\text { System dapat menyesuaikan } \\
\text { dengan lingkungan atau platform } \\
\text { yang baru }\end{array}$ \\
\hline instalability & $\begin{array}{l}\text { System dapat dipasang di berbagai } \\
\text { lingkungan }\end{array}$ \\
\hline coexistence & $\begin{array}{l}\text { System dapat berdampingan } \\
\text { dengan system atau modul lain }\end{array}$ \\
\hline replaceability & $\begin{array}{l}\text { System dapat digunakan untuk } \\
\text { menggantikan atau melanjutkan } \\
\text { dari perangkat lunak sebelumnya }\end{array}$ \\
\hline
\end{tabular}

\section{METODOLOGI PENELITIAN}

\subsection{Pengumpulan Data}

a. Studi literatur

Studi literatur dilakukan untuk mengumpulkan referensi, data atau fakta yang berkaitan dengan penelitian. Pustaka yang dimaksud bisa berasal dari buku teks, jurnal penelitian, prosiding seminar, dan laporan tahunan.

b. Kuesioner

Data dikumpulkan dengan metode survey. Penelitian ini merupakan penelitian dengan menggunakan data kuantitatif dengan memberikan pertanyaan yang dibuat oleh peneliti untuk mengetahui tingkat kualitas aplikasi SAKTI berdasarkan karakteristik pengujian yang terdapat pada ISO 9261.

\subsection{Pemilihan Sample}

Pada penelitian ini, Teknik pengambilan sample menggunakan random sampling. Sample penelitian diambil dari beberapa elemen system. Diantaranya adalah dosen, mahasiswa dan staff biro administrasi akademik. Jumlah sample mencapai 75 orang.

\subsection{Prosedur Penelitian}

Pada penelitian ini digunakan metode analisis kuantitatif deskriptif untuk mendeskripsikan hasil Analisa secara deskriptif berdasarkan hasil kuesioner yang diolah secara kuantitatif. Diawali dari pengidentifikasian masalah dan merumurkan masalah yang ingin diangkat dan diselesaikan, dilanjutkan dengan mengumpulkan teori dan data yang diperlukan dengan melakukan studi pustaka dan yang terakhir merumuskan kerangka evaluasi lalu menyebarkan kuesioner evaluasi dan menganalisisnya.

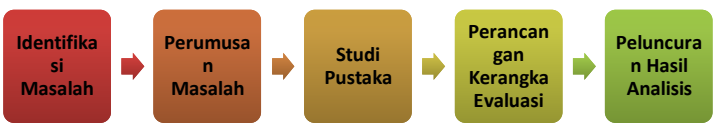

Gambar 2. Prosedur Penelitian

\section{HASIL DAN PEMBAHASAN}

\subsection{Tahap Penyusunan Kerangka Evaluasi}

Sistem akan dievaluasi berdasarkan fungsionalitas, keandalan, kebergunaan, efisiensi, maintainability dan portability. Pada penelitian ini akan digunakan skala likert untuk nilai dan bentuk tes untuk skal likert adalah bentuk pernyataan atau evaluasi objektif / subjektif. Terdapat lima kategori yang digunakan dalam skala likert, yaitu:

Tabel 2. Skala Likert untuk Penilaian Kategori

\begin{tabular}{ll}
\hline \multicolumn{1}{c}{ Pernyataan Positif } & \multicolumn{1}{c}{ Pernyataan Negatif } \\
\hline 1: sangat tidak setuju & 1: sangat tidak setuju \\
2: tidak setuju & 2: tidak setuju \\
3: ragu-ragu & 3: ragu-ragu \\
4: setuju & 4: setuju \\
5: sangat setuju & 5: sangat setuju \\
\hline
\end{tabular}

Sesuai dengan prosedur penelitian, perlu dirumuskan format kuesioner yang akan disebarkan kepada responden. Kuesioner ini harus mengandung unsurunsur penilaian berdasarkan standard ISO 9126. Pada tabel 3 akan dipaparkan format kuesioner yang disebar kepada responden untuk mendapatkan data evaluasi sistem sebelum nantinya akan dianalisis dan ditarik kesimpulan. Pada kuesioner ini akan memuat karakteristik utama ISO 9126 yakni Functionality, Reliability, Usability, Efficiency, Maintainability, Portability (Wicaksono, 2016).

Tabel 3. Karakteristik Kuesioner dengan ISO 9126

\begin{tabular}{|c|c|c|c|}
\hline \multicolumn{4}{|c|}{ FUNCTIONALITY } \\
\hline No & Pernyataan & Sub-karakteristik & Nilai \\
\hline 1 & $\begin{array}{l}\text { Sistem dapat } \\
\text { mudah dimengerti } \\
\text { oleh mahasiswa }\end{array}$ & Suitability & \\
\hline 2 & $\begin{array}{l}\text { Fungsi tombol } \\
\text { dapat berjalan } \\
\text { sebagaimana } \\
\text { mestinya }\end{array}$ & suitability & \\
\hline 3 & $\begin{array}{l}\text { Data yang } \\
\text { diinputkan aman } \\
\text { dan tidak } \\
\text { disalahgunakan }\end{array}$ & accuracy & \\
\hline 4 & $\begin{array}{l}\text { Sistem dapat } \\
\text { memfasilitasi } \\
\text { proses perwalian } \\
\text { mahasiswa dengan } \\
\text { mudah }\end{array}$ & suitability & \\
\hline 5 & $\begin{array}{l}\text { Sistem dapat } \\
\text { menampilkan } \\
\text { laporan akademik } \\
\text { (Seperti IP } \\
\text { Kumulatif, IP } \\
\text { semester) secara } \\
\text { interaktif }\end{array}$ & Suitability & \\
\hline & RE & IABILITY & \\
\hline
\end{tabular}




\begin{tabular}{|c|c|c|c|}
\hline No & Pernyataan & Sub-karakteristik & Nilai \\
\hline 1 & $\begin{array}{l}\text { Sistem dapat } \\
\text { memberikan } \\
\text { informasi terkait } \\
\text { kesalahan saat } \\
\text { proses input data } \\
\text { atau pelaporan }\end{array}$ & Fault tolerance & \\
\hline 2 & $\begin{array}{l}\text { Sistem dapat } \\
\text { memberikan } \\
\text { panduan untuk } \\
\text { memperbaiki } \\
\text { kesalahan saat } \\
\text { melakukan sebuah } \\
\text { proses }\end{array}$ & recoverability & \\
\hline 3 & $\begin{array}{l}\text { Sistem layak } \\
\text { digunakan untuk } \\
\text { membantu semua } \\
\text { proses bisnis } \\
\text { akademik }\end{array}$ & maturity & \\
\hline 4 & $\begin{array}{l}\text { Dalam proses } \\
\text { pencarian data, } \\
\text { sistem dapat } \\
\text { memberikan } \\
\text { informasi yang } \\
\text { akurat }\end{array}$ & Fault tolerance & \\
\hline \multicolumn{4}{|c|}{ USABILITY } \\
\hline No & Pernyataan & Sub-Karakteristik & Nilai \\
\hline 1 & $\begin{array}{l}\text { Sistem dapat } \\
\text { digunakan dengan } \\
\text { mudah } \\
\text { dioperasikan } \\
\text { meskipun ada } \\
\text { kustomisasi form } \\
\text { dan laporan }\end{array}$ & understandability & \\
\hline 2 & $\begin{array}{l}\text { Dalam pelaporan } \\
\text { atau output dari } \\
\text { sistem dapat } \\
\text { dipelajari dengan } \\
\text { mudah oleh } \\
\text { pengguna }\end{array}$ & learnability & \\
\hline 3 & $\begin{array}{l}\text { Penggunaan } \\
\text { SAKTI sangat } \\
\text { mudah untuk } \\
\text { dimengerti karena } \\
\text { tampilannya sangat } \\
\text { familiar oleh } \\
\text { pengguna }\end{array}$ & operability & \\
\hline 4 & $\begin{array}{l}\text { Dalam } \\
\text { implementasinya, } \\
\text { menu dan konten } \\
\text { yang ada pada } \\
\text { sistem sudah sesuai } \\
\text { dengan fungsinya }\end{array}$ & attractiveness & \\
\hline 5 & $\begin{array}{l}\text { Data pengguna } \\
\text { terlindungi dengan } \\
\text { aman dari user luar }\end{array}$ & recoverability & \\
\hline \multicolumn{4}{|c|}{ EFFICIENCY } \\
\hline No & Pernyataan & Sub-Karakteristik & Nilai \\
\hline 1 & $\begin{array}{l}\text { Dengan adanya } \\
\text { SAKTI, user dapat } \\
\text { melakukan proses } \\
\text { akademik (seperti } \\
\text { perwalian) sesuai } \\
\text { dengan waktu yang } \\
\text { telah ditentukan }\end{array}$ & Time behaviour & \\
\hline 2 & $\begin{array}{l}\text { Dengan adanya } \\
\text { SAKTI, user } \\
\text { mematuhi jam } \\
\text { kerja sesuai dengan } \\
\text { waktu yang telah } \\
\text { ditentukan }\end{array}$ & Time behaviour & \\
\hline 3 & $\begin{array}{l}\text { Proses perekaman / } \\
\text { penyimpanan data } \\
\text { untuk setiap proses } \\
\text { bisnis lebih cepat }\end{array}$ & Resource behaviour & \\
\hline
\end{tabular}

\begin{tabular}{|c|c|c|c|}
\hline & $\begin{array}{l}\text { setelah adanya } \\
\text { SAKTI }\end{array}$ & & \\
\hline 4 & $\begin{array}{l}\text { Dalam } \\
\text { implementasinya, } \\
\text { SAKTI mampu } \\
\text { memberikan } \\
\text { efisiensi waktu } \\
\text { dalam } \\
\text { melaksanakan } \\
\text { proses bisnisnya }\end{array}$ & Resource behaviour & \\
\hline \multicolumn{4}{|c|}{ MAINTAINABILITY } \\
\hline No & Pernyataan & Sub-Karakteristik & Nilai \\
\hline 1 & $\begin{array}{l}\text { Hasil pengujian } \\
\text { sistem adalah jika } \\
\text { terjadi kesalahan } \\
\text { makan akan } \\
\text { memberikan pesan } \\
\text { error yang } \\
\text { informatif }\end{array}$ & instrument & \\
\hline 2 & $\begin{array}{l}\text { Bentuk setiap } \\
\text { komponen (seperti } \\
\text { button, panel } \\
\text { navigasi dan lain- } \\
\text { lain) terlihat } \\
\text { konsisten. } \\
\text { Bentuknya sama } \\
\text { namun hanya beda } \\
\text { fungsi }\end{array}$ & consistency & \\
\hline 3 & $\begin{array}{l}\text { Sistem mudah } \\
\text { dikembangkan } \\
\text { untuk improvisasi }\end{array}$ & simplicity & \\
\hline \multicolumn{4}{|c|}{ PORTABILITY } \\
\hline No & Pernyataan & Sub-Karakteristik & Nilai \\
\hline 1 & $\begin{array}{l}\text { Sistem dapat } \\
\text { berjalan di } \\
\text { platform windows } \\
7 \text {, windows } 8 \text { dan } \\
\text { windows } 10\end{array}$ & instrument & \\
\hline 2 & $\begin{array}{l}\text { Sistem dapat } \\
\text { berjalan di } \\
\text { lingkungan linux }\end{array}$ & consistency & \\
\hline 3 & $\begin{array}{l}\text { Sistem dapat } \\
\text { diakses di platform } \\
\text { mobile }\end{array}$ & simplicity & \\
\hline
\end{tabular}

\subsection{Perhitungan Evaluasi}

Dari total 75 responden yang menggunakan aplikasi SAKTI sebagai fasilitator akademik mereka sudah memberikan jawaban yang valid sesuai dengan karakteristik sistem. Dari data kuesioner ini kemudian akan dianalisis berdasarkan karakteristiknya. Hasil dari tanggapan responden dapat diukur berdasarkan rumus berikut:

presentase $=\frac{\text { skor aktual }}{\text { skor ideal }} * 100 \%$

Keterangan:

1. Skor Aktual: total jawaban dari responden atas kuesioner yang diberikan.

2. Skor Ideal: total jawaban responden dengan diasumsikan responden memilih jawaban dengan nilai paling tinggi.

Selanjutnya hasil dari perhitungan skor akan ditranslasikan dengan kriteria yang telah ditetapkan pada tabel 4 berikut. 
Tabel 4. Kriteria Presentase Tanggapan Responden Terhadap

\begin{tabular}{ccc}
\hline No & \% Jumlah Skor & Kriteria \\
\hline 1 & $20.00-36.00$ & Tidak baik \\
\hline 2 & $36.01-52.00$ & Kurang baik \\
\hline 3 & $52.01-68.00$ & Cukup \\
\hline 4 & $68.01-84.00$ & Baik \\
\hline 5 & $84.02-100$ & Sangat baik \\
\hline
\end{tabular}

\subsection{Hasil Analisis}

Setelah dikumpulkannya data tanggapan responden dan dianalisis menggunakan perhitungan presentase maka didapatkanlah hasil seperti yang tampak pada tabel 5. Secara fungsional, sistem sudah berjalan baik. Sistem dapat menyediakan fungsi-fungsi yang dapat menyelesaikan tugas tertentu untuk mencapai tujuan. Sistem juga tergolong efisien, karena sistem dapat merespon dengan cepat sesuai dengan waktu proses yang telah disepakati serta sistem dapat menggunakan seluruh sumberdaya yang dimiliki terutama saat melaksanakan proses utamanya.

Hasil analisis juga menunjukkan bahwa sistem dapat mendiagnosa kekurangan atau error saat runtime dengan baik. Sistem juga dapat dimodifikasi sesuai dengan kebutuhan dan tetap stabil. Selain itu sistem juga dapat berjalan di berbagai platform dengan baik. Namun yang tak kalah penting adalah sistem dapat dipahami oleh user dengan baik serta dapat dipelajari dengan mudah.

Tabel 5. Hasil Analisis Tanggapan Responden

\begin{tabular}{cccc}
\hline No & Karakteristik & Nilai (\%) & Hasil \\
\hline $\mathbf{1}$ & Functionality & 79 & Baik \\
\hline $\mathbf{2}$ & Efficiency & 75 & Baik \\
\hline $\mathbf{3}$ & Maintainability & 75 & Baik \\
\hline $\mathbf{4}$ & Portability & 80 & Baik \\
\hline $\mathbf{5}$ & Reliability & 75 & Baik \\
\hline $\mathbf{6}$ & Usability & 79 & Baik \\
\hline
\end{tabular}

\section{KESIMPULAN DAN SARAN}

Berdasarkan dari pelaksanaan prosedur penelitian mulai dari pengumpulan data hingga analisis tanggapan responden terhadap aplikasi SAKTI maka dapat disimpulkan bahwa sistem mendapat hasil Baik dalam semua aspek karakteristik software berdasarkan ISO 9126. Meskipun begitu, terdapat beberapa hal yang perlu dievaluasi lebih lanjut. Semisal, aplikasi SAKTI saat ini masih menggunakan protokol HTTP, bukan HTTPS sehingga rawan akan man-in-the-middle attack. Ada juga kemungkinan pihak pengembang ragu untuk mengembangkan sistem karena kekhawatiran akan terganggunya fungsi lain apabila fitur baru diintegrasikan ke dalam sistem. Seperti contoh, ada query yang berjalan cukup lambat sehingga seluruh sistem tidak akan berjalan apabila query ini belum selesai. Untuk selanjutnya perlu adanya kajian lebih lanjut mengenai penambahan dan pengintegrasian fitur baru di dalam sebuah sistem yang kompleks.

\section{DAFTAR PUSTAKA}

FEBRERO, F., CALERO, C. AND MORAGA, M. Á. 2016. Software reliability modeling based on ISO/IEC SQuaRE. Information and Software Technology, 70, pp. 18-29. doi: 10.1016/j.infsof.2015.09.006.

LAILELA, S. N. \& SUWARTIKA, R. 2018 Pengukuran Kualitas Perangkat Lunak Aplikasi Sisfo _ Nilai Di Politeknik Piksi Ganesha Berdasarkan Iso 9126. (Selisik).

OUHBI, S. et al. 2015. Applying ISO/IEC 25010 on Mobile Personal Health Records', pp. 405412. doi: $10.5220 / 0005216604050412$.

PADAYACHEE, I. 2010. ISO 9126 external systems quality characteristics, sub- characteristics and domain specific criteria for evaluating eLearning systems', (May 2014).

SCOTT, G. M. 1986. Sistem Informasi Manajemen. PT Pustaka Binaman Pressindo.

SIMANJUNTAK, O. S. 2013. Sistem Informasi Akademik dengan Menggunakan Standar Iso 9126', 2013(semnasIF), pp. 315-319.

SISTEM, R., DWI, P. \& PAMUNGKAS, A. 2018. ISO 9126 Untuk Pengujian Kualitas Aplikasi Perpustakaan Senayan', 2(2), pp. 465-471.

WEBER, R. (Ronald) \& A., R. 1999. Information systems control and audit', p. 14. Available at: https://dl.acm.org/citation.cfm?id=601500.

WICAKSONO, H. 2016. Audit Kualitas Software ERP Axapta Menggunakan Standard ISO 9126', 3(1), pp. 107-121. 